\title{
The 'Conventionalisation' Thesis Reconsidered: Structural and Ideological Transformation of Australian Organic Agriculture
}

\author{
Stewart Lockie and Darren Halpin
}

\begin{abstract}
C
ontemporary narratives on organic food and agriculture are almost inevitably tales of extraordinary growth (see Michelson 200Ia). In the UK, for example, Smith and Marsden (2003) report a ninefold increase in the area of land certified for organic production between 1996 and 2000 . For many, the practical possibilities offered by the organic sector to supply food untainted by agrichemicals, genetically-modified organisms and other 'unnatural' technologies provides compelling evidence of growing consumer and producer resistance to the risks they associate with agri-industrial production methods (Kaltoft 200I). For others, the possibilities offered by the organic sector to resist the erasure of tradition, community and place associated with agri-industrialisation speak to conceptions of food quality that extend beyond the physical and chemical composition of foodstuffs (Goodman I999; Pugliese 200I; Smith and Marsden 2003). Organic agriculture-along with a range of other alternative agricultural and food movements-is seen to produce foods that are not only good to eat, but good to think. This is not to suggest that organic agriculture is without its critics. Some accuse the organic industry of everything from fraudulent environmental and food safety claims to endangering food security and biodiversity (see Lockie, forthcoming). Nevertheless, the dominant framings of organic food and farming are of a sector that is fundamentally counterpoised against the homogeneity, placelessness, artificiality, blandness and threats of industrially-produced foods and global brands (Lockie, forthcoming).

Accompanying growth of the organic sector, however, have been another set of narratives that have featured prominently in this journal. What has become known as the 'conventionalisation thesis' may be characterised as a collection of cautionary tales that, although not critical of organic food and agriculture per se, raise concerns about a number of changes within the sector that either have, or may, accompany its growth. The implicit, yet clear, normative thread here is to retrieve or save the organic sector from corruption by the patterns of practice and thought associated with conventional agriculture. To summarise this thesis crudely, conventionalisation refers to a process through which
\end{abstract}

Published by Blackwell Publishing, 9600 Garsington Road, Oxford OX4 2DQ, UK 350 Main Street, Malden, MA02148, USA
Sociologia Ruralis, Vol 45, Number 4, October 2005 (C) European Society for Rural Sociology ISSN 0038-0199 
organic agriculture comes increasingly, as it grows, to resemble in structure and ideology the mainstream food sector it was established in opposition to. Importantly, while the theoretical roots of the conventionalisation thesis may be traced to a series of articles by Julie Guthman and collaborators (beginning with Buck et al. I997), the observations and concerns that underlie this concept feature prominently in the contemporary politics of the organic movement. But despite the apparent scholarly and practical significance of conventionalisation, there is considerable disagreement among researchers and movement actors alike over its dynamics and meaning.

This article seeks to contribute to this debate through an examination of structural and ideological change in the Australian organic industry; a contribution that we will claim is significant in at least four inter-related ways. First, by documenting more adequately what actually is going on in at least one national organic agriculture sector which has been characterised, to date, by a relative paucity of reliable data, this article will make a small contribution to our empirical understanding of structural and ideological change in organic production. Second, while we will not make the claim that the Australian case represents the paradigmatic importance Guthman (2004a) ascribes to California as a centre of agri-industrial innovation (although the fact that Australia accounts for nearly half of all land worldwide certified for organic production (Yussefi 2004) suggests the Australian case to be of tremendous ecological importance), we will claim that Australia offers useful insights into possible trajectories of change within the organic sector that are of wider empirical and theoretical relevance. Third, by examining commodity groups that, despite sharing similar regulatory environments, demonstrate divergent structures and agroecologies this article will demonstrate that the package of economic and ideological changes associated with 'conventionalisation' are not structural inevitabilities but may, in fact, take a variety of forms. Fourth, these findings suggest a need to retheorise 'conventionalisation' in a manner that recognises more explicitly the role that such concepts play not just in describing and/or explaining, but in attempting to shape, relations of production and consumption.

\section{Conventionalisation and other cautionary tales}

To date, debate over conventionalisation has focussed primarily on the extent to which it may be characterised as either an inevitable or universal phenomena (Guthman 2004a). While it is obvious enough that few, if any, organic production sectors have proceeded as far down the path of agri-industrialisation as California, debate has hinged on whether they will be forced to or whether social movement resistance and/or the strong hand of public policy might maintain the 'alternative' and 'transformative' potential of organics (Hall and Mogyorody 200I; Michelson 200Ia). Oddly, we would suggest, there has been comparatively little debate over what conventionalisation actually is. The empirical trends generally seen to comprise conventionalisation include:

- Concentration of capital among fewer, larger organic producers and market intermediaries. Although the total number of organic producers may still be increasing, it is argued that the price premiums available for organic produce have attracted the interest of larger conventional farmers. Operating at larger economies of scale, the entry of these farms has the potential both to erode price premiums and to displace smaller farms as preferred suppliers to retailers and other intermediaries due to the capacity of larger farms to provide 
greater continuity of supply and lowered transaction costs (Buck et al. 1997). Much of this dynamic has been driven by the increasing interest of large processors, distributors and retailers who have found it cheaper to support a small number of large conventional farms through the organic conversion process than to deal with multiple existing small producers (Guthman 2004b; Lockie et al. 2000; Smith and Marsden 2003).

- $\quad$ Codification and de-radicalisation as the need for clear definitions and production standards underpinned by state regulatory apparatuses - in order to provide a predictable and stable platform for investment-facilitates the transformation of organics from an ecologically and politically innovative social movement to yet another sub-sector within conventional regulatory paradigms and agencies (Guthman 1998; Michelsen 200Ib; Pugliese 200I; Tovey I997). Supporting the redefinition of organic production and consumption as individualised acts aimed at personal financial, sensory or health benefits this, in turn, makes the organic market vulnerable to challenges by other approaches to food safety and quality assurance (Campbell and Coombes I999; Lockie et al. 2000).

- Erosion of standards seen as unfavourable to industrial production by corporate farmers and processors more interested in market access than in traditional organic values and ideologies (Lockie et al. 2000). While explicit challenges to codified standards have been limited by the need for capital to demonstrate its compliance with consumer expectations (Guthman 2004a), non-codified values such as biodiversity, self-sufficiency, energy recycling and community-building are more easily bypassed (Guthman 2000, 2004c).

- Substitution of allowable inputs for proscribed inputs. Organic farms resemble ever more closely the reliance of their conventional counterparts on energy-intensive sources of external inputs and progressively are subsumed within parallel, certified organic, circuits of off-farm capital (Guthman 2004a, 2004c). As with conventional agriculture, organic farmers who resist subsumption in this manner risk losing comparative advantage and market share to other producers as organic farming is subjected to the same cost-price squeeze as conventional agriculture (Guthman 2004b; Smith and Marsden 2003).

- Bifurcation between a 'conventional' organic sector dominated by capital intensive, specialised, vertically-integrated and export oriented growers and a residual artisanal organic sector comprising smaller scale and more diverse enterprises often catering to more localised markets and operating in different production spaces (Buck et al. I997; Coombes and Campbell I998; Campbell and Coombes I999; Campbell and Liepens 200I; Guthman 2004c; Lockie et al. 2002).

- Defensive localism and other 'post-organic' strategies extend bifurcation by aiming to recapture a range of values marginalised through conventionalisation such as local production for local consumption. Often, it is claimed, these initiatives are promulgated by artisanal growers who have chosen to opt out of the highly codified version of organics exemplified in certification standards (Guthman 2004C; Tovey 2002; Moore 2004). However, even here the potential for corporate and/or state capture remains with rapid growth in the phenomena of farmers' markets and their deliberate promotion by state agencies as rural development strategies (Moore 2004).

As stated above, this summary of empirical trends glosses over important differences among contributors to the conventionalisation thesis, particularly over the inevitability, extent, and alternatives to these processes. Also, it ignores a range of equally important cautionary tales beginning to emerge within the literature such as the potential of organic 
standards and certification procedures established in the Global North to marginalise Southern producers (Mutersbaugh 2002, 2004) and the phenomena observed in some parts of northern Europe of large numbers of farmers reverting entirely to conventional production (Kaltoft and Risgaard 2004). Nevertheless, the basic parameters of the conventionalisation thesis as outlined above have played a considerable role in shaping sociological research and debate on organic food and farming while the concept of conventionalisation has promoted interpretation of the above, and other potentially disparate processes, in a variety of locales as part of a (relatively) unitary dynamic. Not surprisingly, these locales include parts of Australia with Jordan et al. (2004) and Lyons (I999, 200I) finding considerable evidence of corporate involvement in organic processing and retailing leading to corresponding shifts in the economic and spatial scale of production units supplying key organic markets.

We do not wish to contest the accuracy or importance of this research. However, we do wish to problematise the binary division evident in the conventionalisation thesis (and its Australian manifestations) between small-scale artisanal producers and large-scale industrial producers in a number of ways. First, case studies of particular corporate ventures as undertaken by Jordan et al. (2004) and Lyons (I999, 200I) provide limited evidence of what is occurring at a wider industry level. There is a very simple need, therefore, for basic statistical data on what is happening beyond these case study sites. Second, we need to unpack the empirical assumptions and not-sosubtle normative evaluations underpinning the terminology of artisanal and industrial production. The process of agri-industrialisation has been extensively theorised-most notably by Goodman et al. (I987) in terms of the creation of input-dependencies and the substitution of one agricultural commodity for another in manufacturing. The unexamined category of artisanal production, however, introduces a range of implicit assumptions about the structural and ideological basis of food production; namely, that smallholder agriculture is less commoditised and its proponents more committed to the preservation of community, tradition, environment and other non-market values. By implication, the operators of larger farms are counterpoised as uncommitted opportunists drawn by niche markets and increased prices. Thus, the binary opposition of artisanal and industrial production conflates differences in economic scale with differences in production practices, market relationships and grower motivations that have not empirically been verified. Within this paper we will, therefore, examine a range of evidence for various components of conventionalisation including, as suggested, issues of scale, market linkages and ideology.

\section{Methodology}

There is no systematic collection of data at a national level on organic agriculture in Australia. The basis for many widely cited estimates of the size and composition of the organic industry also is less than clear. The data used here came from two sources. The first was data routinely collected by several certifying organisations including the National Association for Sustainable Agriculture Australia, Australian Certified Organic, Tasmanian Organic-Dynamic Producers and Safe Food Production Queensland. Three remaining certification bodies either did not collect relevant data or were unwilling to provide that data due to privacy concerns. The reliability of the data provided to us 
was compromised by inconsistent collection protocols, incompleteness, and growers' frequent membership of multiple certifying bodies. Nevertheless, this data provided a useful basis against which to check the validity of the study's primary data source and to calculate multiplication factors.

The second, and primary, source was a telephone-based stratified random sample survey of certified organic and conventional farms conducted by the authors in July 2004. The organic sample for the survey was drawn randomly from a list of certified organic producers (excluding in-conversion and pre-certified farms) constructed from lists publicly available from the National Association for Sustainable Agriculture Australia, Australian Certified Organic, Tasmanian Organic-Dynamic Producers and Organic Growers of Australia together with the Organic Federation of Australia 2002 directory and the Western Australia Organic Farmers' Association 2003 directory. Some 400 certified organic producers were interviewed generating 397 usable responses. This represented a response rate of 42 percent constituting approximately 26 percent of the estimated certified organic farm population of I5II producers (see Halpin 2004 for more detail on the basis for these estimates). This provides a comfortable level of reliability with a relative standard error of 4.32 percent at a confidence level of 95 percent. The survey of organic producers was divided into two main sections, the first of which dealt with the collection of detailed production and marketing detail on behalf of the federal Department of Agriculture, Fisheries and Forestry, and the second of which dealt with the collection of data on motivations for farming, attitudes to key agricultural policy issues, implementation of basic environmental management practices and group membership. The conventional farm sample was drawn from farmers and graziers listed in the Marketing Pro - Business April 2004 Edition (Copyright (C) 2004 Desktop Marketing Systems Pty Ltd), a comprehensive collection of electronic telephone directories. Four hundred and thirty four conventional farmers were surveyed with a similar response rate as for organic growers. Conventional farmers were only administered the second part of the survey administered to organic growers as detailed production data is collected annually by the Australian Bureau of Statistics.

Questions on the motivations for farming were based on a format developed to measure motivations behind food choice developed by Steptoe et al. (I995) and applied in a study of organic food consumption by Lockie et al. (2002). This format treats motivation in a multidimensional manner that avoids forcing artificial choices between potential farming motives and seeks instead to explore the relationships between environmental and other concerns. Based on the review of research into conversion to organic farming by Padel (200I), scales were developed for Io potential motivations including environmental health, animal health, farm productivity, farm profitability, risk aversion, cost saving, premium marketing, food quality, chemical safety and rural development. Each scale took the form of several questions that asked on a typical day, how important is to you farm in a manner that [for example] allows animals to act out natural patterns of behaviour? Each scale was tested for validity following the survey and several items deleted.

Attitudinal scales were developed to address six key issues related to agriculture and organic foods including the seriousness of land degradation, farmers' responsibility to address land degradation, the appropriateness of compensation for restrictions placed on private property rights to protect environmental values, the quality and safety of 
organic foods, the potential benefits of genetic engineering and risks to consumers from consumption of industrially-produced foods. Items comprising these scales were taken from a number of sources including Reeve's (200I) national survey of farmers' attitudes to environmental issues. Questions took the form of five point Likert scale items to which respondents were asked to agree or disagree. Again, each scale was tested for validity after the survey and several items deleted.

\section{Results}

The changing scale of organic production

In spatial terms, the median organic farm size in 2004 was 50 hectares with properties ranging in size from less than one to 447,000 hectares. In economic terms, median gross farm receipts (excluding off-farm income and averaged 200I-2003) were $\$ 50,000$ with a range from zero to $\$ 4.4$ million. For conventional respondents, by contrast, median farm size was 1000 hectares, ranging from one to 8.9 million hectares, and median gross receipts were $\$ 280,000$, ranging from $-\$ 25,000$ to $\$$ Io million. Given that much of the dramatic range in the spatial size of farms is reflective of different enterprise mixes and agroecologies, gross farm receipts will be used throughout this paper as the more accurate measure of farm size. In this respect, some 8.5 percent of certified organic growers reported average annual gross farm receipts of zero and 25.8 percent reported receipts of \$IO,000 or less, suggesting a large number of very small growers basing their livelihoods on a combination of low consumption and off-farm income. Nevertheless, the total distribution of organic farms according to economic scale was not bifurcated but more-or-less normal with a slight skew to the right. If the sample is divided into four groups of equal number the data shows that the first quartile, as reported above, earned \$10,000 or less and the second quartile up to $\$ 50,000$, while the third quartile earned $\$ 50-120,000$ and the top quartile over $\$$ I20,000. Thus, while there were more very small than very large organic growers, the majority fell somewhere in between and over three quarters operated their farms as their main occupation. However, if the economic scale of the industry is examined on the basis of particular product mixes it becomes apparent that there is considerably more evidence of polarisation between broadacre agricultural enterprises (grazing and cereal cropping) and horticulture (vegetable, fruit and nut production). As Figure I shows, over half of all broadacre organic farmers grossed more than $\$ 70,000$ per annum compared with almost no horticulturalists.

Biological Farmers' of Australia (BFA) estimates that between 1990 and 2003 the number of certified producers (including in-conversion) grew from less than 500 to 2200 , the area of certified land from 0.15 to Io million hectares and the domestic retail value of organic production from 28 to 250 million Australian dollars (Moore 2003). The export sector remained relatively small, however, at an estimated \$40 million. Among those product categories growing most rapidly, according to BFA, the export sector was dominated by organic beef production and the domestic sector by fruit and vegetable production. And, of course, the farm gate value of organic produce was significantly lower than the retail or export value at an estimated \$90 million in 2002 (Moore 2003). 
Figure 1: Distribution of gross farm receipts by product type

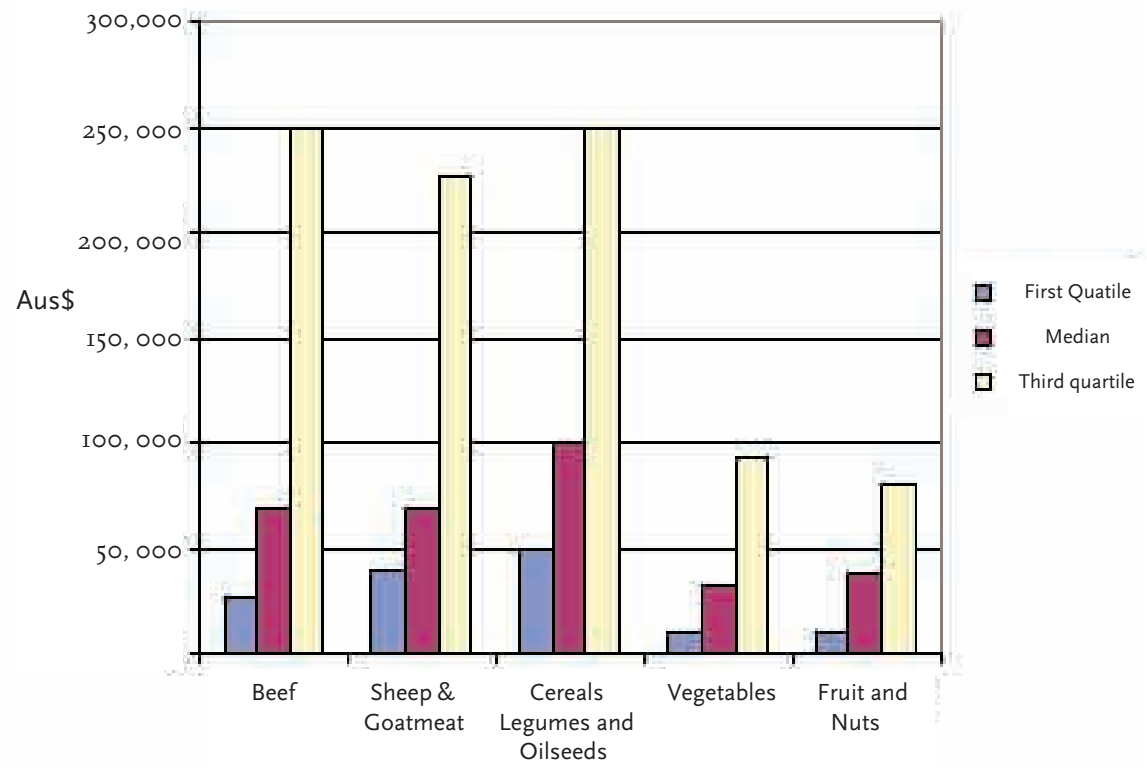

Our own data suggests either that this estimate was unduly conservative or that between 2002 and 2003 sales grew more than the 15 to 30 percent often estimated (Moore 2003). Survey data-despite not including farmers in-conversion and several minor product categories-indicates the farm gate value of organic produce sold as organic in 2003 to have been approximately \$I28 million. Data was not collected on the farm gate value of organic produce sold as conventional although, as Table I shows, this constituted at least a quarter of all sales for most product categories. Strong growth in production may be expected to continue with membership lists provided by certifier groups suggesting that certified grower numbers could rise by over 40 percent in the next three years based solely on the number of producers currently in-conversion or voluntary deferral.

There were no long-term trends that might indicate whether those growers entering the industry in the next few years are more or less likely to be either conventional farmers converting to organic production or new farmers establishing start-up organic enterprises. In fact, the average length of experience among existing certified organic farmers was between six and seven years for converting and start-up operators alike. The likelihood that growers had converted existing farms or begun new organic enterprises was affected most by the specific products they produced. Within the extensive broadacre industries (beef, sheep and goat meat, wool, cereals and oilseeds), between 80 and 90 percent of growers had converted existing conventional enterprises while in the smallholder dominated vegetable and fruit and nut industries only 46 and 56 percent respectively of growers converted existing operations. Reflecting the different product 
mixes, start-up organic operations had smaller average gross farm receipts $(\$ 85,223)$ than converting operations (\$223,3I5).

Table 1: Organic farm production levels and projected change for selected products

\begin{tabular}{|c|c|c|c|c|c|c|}
\hline $\begin{array}{l}\text { Product } \\
\text { category }\end{array}$ & $\begin{array}{l}\text { Estimated } \\
\text { number } \\
\text { of organic } \\
\text { producers } \\
\text { nationally }\end{array}$ & $\begin{array}{l}\text { Sample } \\
\text { size }\end{array}$ & $\begin{array}{c}\text { Mean } \\
\text { conventional } \\
\text { output per } \\
\text { organic } \\
\text { producer }\end{array}$ & $\begin{array}{c}\text { Mean organic } \\
\text { output per } \\
\text { organic } \\
\text { producer }\end{array}$ & $\begin{array}{l}\text { Mean proportion } \\
\text { organic } \\
\text { produce sold as } \\
\text { conventional }\end{array}$ & $\begin{array}{l}\text { Mean projected } \\
\text { change in } \\
\text { organic volume } \\
\text { per producer } \\
2005-2007\end{array}$ \\
\hline $\begin{array}{l}\text { Beef (kgs live } \\
\text { weight) }\end{array}$ & 331 & 87 & 26,465 & 46,992 & $28.8 \%$ & $+28.2 \%$ \\
\hline $\begin{array}{l}\text { Sheep \& goat } \\
\text { meat (kgs live } \\
\text { weight) }\end{array}$ & 118 & 31 & 4,432 & 40,526 & $65.1 \%$ & $+71.9 \%$ \\
\hline $\begin{array}{l}\text { Pork (kg live } \\
\text { weight) }\end{array}$ & 19 & 5 & ० & 5,900 & $4.7 \%$ & $+152.0 \%$ \\
\hline $\begin{array}{l}\text { Poultry (kg live } \\
\text { weight) }\end{array}$ & 27 & 7 & o & 2,413 & $10.4 \%$ & $+74.3 \%$ \\
\hline Eggs (dozen) & 68 & 18 & o & 5,628 & ०\% & $+59.4 \%$ \\
\hline Milk (litres) & 57 & 15 & 177,280 & 426,026 & $38.0 \%$ & $+40.7 \%$ \\
\hline $\begin{array}{l}\text { Cereals, } \\
\text { legumes } \\
\text { \& oilseeds } \\
\text { (tonnes) }\end{array}$ & 217 & 57 & 8 & 261 & $27.3 \%$ & $+36.3 \%$ \\
\hline $\begin{array}{l}\text { Vegetables } \\
\text { (tonnes) }\end{array}$ & 486 & 128 & 1 & 225 & $0.3 \%$ & $+89.2 \%$ \\
\hline $\begin{array}{l}\text { Fruit \& nuts } \\
\text { (tonnes) }\end{array}$ & 593 & 156 & 10 & 44 & $24.6 \%$ & $+95.7 \%$ \\
\hline
\end{tabular}

There also were no long-term trends that might indicate whether farmers entering the organic industry over the next few years are likely to be any larger or smaller than existing growers. The survey data revealed no statistically significant correlations between the length of time respondents had been certified as organic farmers and the size or value of their operations (although there were small positive correlations between length of time as a certified organic producer, the proportion of farm area devoted to organic production and the proportion of farm income derived from organic produce). Further, as Table I shows, existing organic producers planned considerable expansion of their operations over the three years following the survey with generally higher levels of expansion forecast in the intensive horticultural industries than in the broadacre grazing and cropping industries (NB. small sample sizes for pork, poultry, eggs and milk suggests the need for caution interpreting statistics for these products). Again, there were no statistically significant relationships between the recency of farmers' entry into organic production and their expected levels of expansion. Neither, with the exception of pigmeat, were there significant correlations between the size of farm enterprises and intentions to expand them. Among beef producers, there was a moderate correlation $(\mathrm{rho}=.293, \mathrm{p}=.02 \mathrm{I})$ between projected expansion of organic production and existing production of conventionally produced beef. 


\section{Market linkages}

As stated above, Biological Farmers' of Australia (Moore 2003) claim that growth in exports of Australian organic products are dominated by beef and growth in domestic organic markets dominated by fruit and vegetables. However, the total size of the Australian organic export sector in 2002 was only $\$ 40$ million, the bulk of which was comprised (by volume), as shown in Table 2, of cereals. Table 2 also shows exports of meats and cereals to have fallen dramatically between 200I and 2003. While it is possible that much of this decline reflected prolonged drought conditions in major broadacre farming areas rather than any likely long-term trend, it is clear both that the export future for Australian organic produce is highly unstable and uncertain and that the majority of Australian organic beef remains destined for domestic consumption.

Table 2: Exports of Australian organic food produce by standardised net mass, tonnes or kilolitres (Halpin 2004)

\begin{tabular}{lrrrrr}
\hline & 1999 & 2000 & 2001 & 2002 & 2003 \\
\hline $\begin{array}{l}\text { Animal products (milk, honey, eggs } \\
\text { etc) }\end{array}$ & 20 & 204 & 190 & 157 & 183 \\
Beverage and spices & 0 & 249 & 715 & 397 & 224 \\
Cereals (grains, pulses and oilseeds) & 252 & 10,572 & 26,307 & 9,290 & 1,298 \\
Drinks and juices & 4 & 40 & 425 & 724 & 380 \\
Fruit and nuts & 10 & 558 & 696 & 452 & 44 \\
Meat products & $<1$ & 102 & 396 & 682 & 244 \\
Processed products & 463 & 3,073 & 6,095 & 3,843 & 1,197 \\
Sugar & 1 & $<1$ & 4 & 87 & 141 \\
Vegetables & 3 & 921 & 2449 & 227 & 119 \\
Wine & 19 & 49 & 188 & 336 & 244 \\
Other & 1 & 0 & 5 & 1 & 16 \\
Total & 774 & 15,770 & 37,470 & 16,195 & 4,089 \\
\hline
\end{tabular}

Note: due to the effects of rounding column totals may vary slightly from actual totals

If we examine the channels through which organic produce was sold it emerges (see Table 3) that while the bulk was directed through intermediaries and processors, substantial quantities also were sold direct to consumers and retailers. While standard deviations for the mean proportion of produce sold through the various channels was high, this was less the case in relation to sales direct to consumers than it was with other marketing options. Examination of the data underlying Table 3 showed a remarkably common strategy for farmers across most of these product groups was to sell a small proportion-in the range of to to 25 percent-of their produce direct to consumers and the rest to a single intermediary, processor or retailer (see Halpin 2004). Despite the dependence of most producers on single marketing outlets, with the exception of milk, very few producers had formal agreements such as contracts or license agreements 
with their supply chain partners. There were no significant relationships between the use of particular marketing channels-including sales direct to consumers-and enterprise size measured either in volume or value of output. Few farmers were engaged, or expressed interest in, participation in horizontal market collaboration such as cooperatives to provide greater continuity and volume of supply.

Table 3: Estimated mean proportion of organic produce sold as organic through different marketing channels

\begin{tabular}{lccccc}
\hline & $\begin{array}{c}\text { Number of } \\
\text { respondents }\end{array}$ & Consumers & $\begin{array}{c}\text { Intermediaries } \\
\text { (incl. agents, } \\
\text { consolidators, } \\
\text { wholesalers) }\end{array}$ & Processors & $\begin{array}{c}\text { Retailers (incl. } \\
\text { food service } \\
\text { outlets) }\end{array}$ \\
\hline Beef & 84 & $14 \%$ & $39 \%$ & $29 \%$ & $19 \%$ \\
Sheep \& goat meat & 29 & $14 \%$ & $36 \%$ & $23 \%$ & $41 \%$ \\
Pork & 5 & $10 \%$ & $0 \%$ & $48 \%$ & $42 \%$ \\
Poultry & 7 & $22 \%$ & $23 \%$ & $0 \%$ & $41 \%$ \\
Eggs & 18 & $26 \%$ & $43 \%$ & $2 \%$ & $39 \%$ \\
Milk & 9 & $5 \%$ & $30 \%$ & $55 \%$ & $18 \%$ \\
Cereals, pulses \& & 52 & $10 \%$ & $27 \%$ & $49 \%$ & $1 \%$ \\
oilseeds & 119 & $21 \%$ & $65 \%$ & $1 \%$ & $18 \%$ \\
Vegetables & 141 & $14 \%$ & $63 \%$ & $8 \%$ & $15 \%$ \\
Fruit \& nuts & & & &
\end{tabular}

Note: as respondents were asked to estimate percentage of output sold to each source separately, percentages do not sum to exactly 100 percent.

\section{Motivations, attitudes and beliefs}

While the data presented in this section may be examined from a variety of useful perspectives, we will restrict our examination here to those issues particularly pertinent to processes of so-called conventionalisation; in particular the 'bifurcation' plank of the conventionalisation thesis. Table 4 shows the items and reliability for scales on motivations for farming. Given the obvious social desirability of several of these motivations an attempt was made to ensure that items addressed the specific issues involved in their implementation — so as to differentiate satisfactorily between producers - without introducing items that would specifically discriminate against conventional farmers. The animal health scale scored respondents on their level of motivation to ensure that animals were enabled to act out normal patterns of behaviour and to tolerate minimum chemical intervention rather than simply to be productive or free of disease.

The environmental health scale addressed those issues explicitly raised in traditional organic farming ideology of biodiversity and energy and nutrient recycling rather than simply the absence of obvious land degradation. Productivity motivations were measured in terms of production and output. Profitability motivations were measured in terms of viability and return on investment as well as in terms of maximising net returns. Cost saving dealt primarily with the reduction of off-farm inputs but did not differentiate between 
Table 4: Scale items and reliability-motivations for farming

\begin{tabular}{|c|c|c|}
\hline Scale & Items & $\begin{array}{c}\text { Reliability } \\
\text { (Cronbach's alpha) }\end{array}$ \\
\hline Animal health & $\begin{array}{l}\text { ensuring animals can act out normal patterns of behaviour } \\
\text { reducing use of chemicals to maintain animal health } \\
\text { maximising biological diversity } \\
\text { conserving native flora and fauna }\end{array}$ & $.56 \mathrm{I7}$ \\
\hline Environmental health & $\begin{array}{l}\text { minimising soil erosion } \\
\text { improving the biological health of the soil } \\
\text { maintaining processes of nutrient and energy recycling } \\
\text { increasing production }\end{array}$ & .7457 \\
\hline Productivity & $\begin{array}{l}\text { maximising outputs } \\
\text { maximising profits } \\
\text { ensuring a healthy return on investment }\end{array}$ & $.8 \mathrm{I} 42$ \\
\hline Cost saving & $\begin{array}{l}\text { reducing farm costs } \\
\text { reducing use of expensive farm inputs }\end{array}$ & .6228 \\
\hline Premium marketing & $\begin{array}{l}\text { producing products that can attract a price premium } \\
\text { targeting a lucrative niche market }\end{array}$ & .6339 \\
\hline Risk aversion & $\begin{array}{l}\text { avoiding any sort of financial risk } \\
\text { implementing practices that are reasonably certain to turn a } \\
\text { profit } \\
\text { avoiding farm debt }\end{array}$ & .5278 \\
\hline Chemical safety & $\begin{array}{l}\text { reducing your exposure to farm chemicals } \\
\text { reducing your family's exposure to farm chemicals }\end{array}$ & .8794 \\
\hline Food quality & $\begin{array}{l}\text { producing food that is nutritious } \\
\text { producing food that is free of traces of hormones or chemicals }\end{array}$ & .6722 \\
\hline Rural development & $\begin{array}{l}\text { contributing to the regional economy } \\
\text { contributing to the generation of local employment }\end{array}$ & .7012 \\
\hline
\end{tabular}

synthetic and allowable organic inputs. Premium marketing also avoided discrimination against the niche marketing activities of conventional producers by measuring motivation towards niche marketing and the production of premium products without mentioning organic produce markets. Risk aversion addresses the trade-offs that farmers often make, at the expense of potential profitability, to cope with unpredictable production and market environments. Chemical safety dealt with respondents' motivation to reduce exposure both to themselves and their families. Food quality dealt with nutrition and 
food safety. Although the food safety scale dealt explicitly with chemical residues it is not believed that this discriminated against conventional producers as most industries are now covered by quality assurance schemes, voluntary codes of conduct, and so on, involving minimum withholding periods and other means of reducing food-borne risk. Rural development addressed producers' motivation towards contributing economically to their local communities.

Figure 2: Mean scores among organic and conventional farmers - motivations for farming

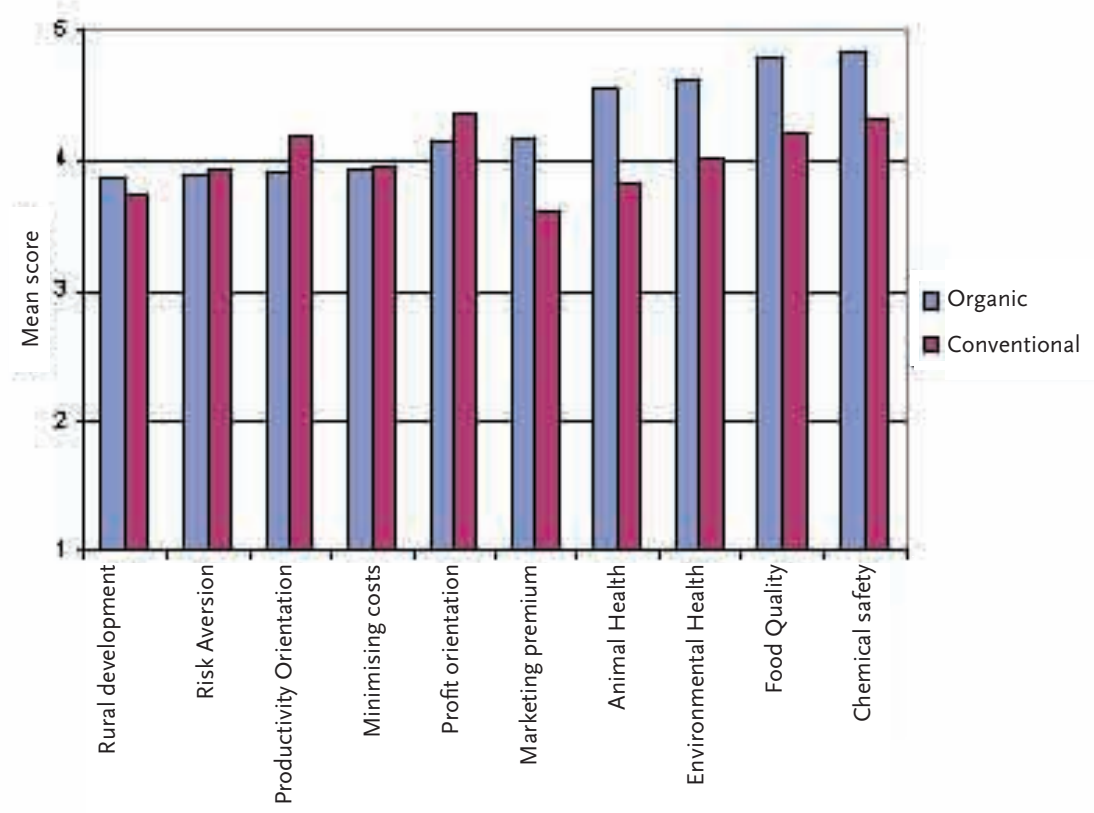

Figure 2 shows substantial differences between organic and conventional farmers in relation to those motivating factors most important to organic farmers-chemical safety, food quality, environmental health, and animal health. Organic farmers were also more strongly motivated, albeit to a lesser extent, to market their produce at a premium. This is not to say that conventional farmers did not consider any of these motivations important but that, relatively speaking, they were of lower priority than they were for organic farmers. Conventional farmer were significantly more motivated than organic farmers to maximise productivity and profits. These stood alongside chemical safety and food quality as the most important motivating factors for conventional farmers. Both groups were equally motivated towards minimising costs, risk aversion and rural development, all of which were somewhat less important than other motivating factors. 
Table 5: Mean scores and t-values among organic and conventional farmers - motivations for farming

\begin{tabular}{|c|c|c|c|c|c|c|c|}
\hline & $\begin{array}{c}\text { Are you a } \\
\text { certified } \\
\text { organic } \\
\text { producer? }\end{array}$ & $\mathrm{N}$ & Mean & $\begin{array}{c}\text { Std. } \\
\text { Deviation }\end{array}$ & $\begin{array}{l}\text { Std. Error } \\
\text { Mean }\end{array}$ & t-value & Significance \\
\hline \multirow[t]{2}{*}{ Animal health } & YES & $28 \mathrm{I}$ & 4.5480 & .6127 & $3.655 \mathrm{E}-\mathrm{O} 2$ & I2.970 & $.000 * * *$ \\
\hline & NO & 360 & 3.8222 & $.804 \mathrm{I}$ & $4.238 \mathrm{E}-02$ & & \\
\hline \multirow{2}{*}{$\begin{array}{l}\text { Environmental } \\
\text { health }\end{array}$} & YES & 357 & 4.6095 & .4419 & $2.339 \mathrm{E}-\mathrm{O} 2$ & I4.599 & $.000 * * *$ \\
\hline & NO & 330 & 4.0236 & .5924 & $3.26 \mathrm{IE}-02$ & & \\
\hline \multirow{2}{*}{$\begin{array}{l}\text { Productivity } \\
\text { orientation }\end{array}$} & YES & 376 & 3.9003 & .8664 & $4 \cdot 468 \mathrm{E}-02$ & -5.094 & $.000 * * *$ \\
\hline & NO & $4 \mathrm{I} 4$ & 4.2029 & .8032 & $3 \cdot 948 \mathrm{E}-02$ & & \\
\hline \multirow[t]{2}{*}{ Profit orientation } & YES & 375 & $4 \cdot 1422$ & .7708 & $3.980 \mathrm{E}-\mathrm{O} 2$ & -4.408 & $.000 * * *$ \\
\hline & NO & $4 \mathrm{I} 8$ & 4.3604 & .6018 & $2.944 \mathrm{E}-02$ & & \\
\hline \multirow[t]{2}{*}{ Minimising costs } & YES & 344 & 3.9409 & .7218 & $3.892 \mathrm{E}-\mathrm{O} 2$ & -.230 & $.8 \mathrm{I} 8 \mathrm{~ns}$ \\
\hline & NO & 397 & 3.9530 & .7035 & $3 \cdot 53 \mathrm{IE}-\mathrm{O} 2$ & & \\
\hline \multirow{2}{*}{$\begin{array}{l}\text { Marketing } \\
\text { premium }\end{array}$} & YES & 377 & 4.1684 & .7267 & $3.743 \mathrm{E}-02$ & $8.82 \mathrm{I}$ & $.000 * * *$ \\
\hline & NO & $38 \mathrm{I}$ & $3.6 \mathrm{I} 8 \mathrm{I}$ & 9743 & 4.99IE-O2 & & \\
\hline \multirow[t]{2}{*}{ Risk aversion } & YES & 367 & 3.8919 & .6740 & $3 \cdot 5 \mathrm{I} 8 \mathrm{E}-\mathrm{O} 2$ & -.764 & $.445 \mathrm{~ns}$ \\
\hline & NO & 409 & 3.9283 & .6503 & $3.216 \mathrm{E}-02$ & & \\
\hline \multirow[t]{2}{*}{ Chemical safety } & YES & 344 & 4.8328 & .3880 & $2.092 \mathrm{E}-\mathrm{O} 2$ & II.I72 & $.000 * * *$ \\
\hline & NO & 405 & $4 \cdot 3333$ & .7953 & $3.952 \mathrm{E}-02$ & & \\
\hline \multirow[t]{2}{*}{ Food quality } & YES & 374 & $4.786 \mathrm{I}$ & .4057 & $2.098 \mathrm{E}-02$ & $\mathrm{I} 3.274$ & $.000 * * *$ \\
\hline & NO & 392 & 4.2207 & .7340 & $3.707 \mathrm{E}-02$ & & \\
\hline \multirow[t]{2}{*}{ Rural development } & YES & 366 & 3.8620 & .8747 & $4 \cdot 572 \mathrm{E}-\mathrm{O} 2$ & I. 736 & $.083 \mathrm{~ns}$ \\
\hline & NO & 387 & 3.7545 & $.824 \mathrm{I}$ & 4.I89E-O2 & & \\
\hline
\end{tabular}

Note: t-value calculated on unequal variance where Levene's Test for Equality of Variances $\mathrm{p}<.05$. Otherwise equal variance assumed

Among organic farmers, there were no significant differences in the relative importance attributed to any motivating factor on the basis either of farm size, enterprise mix or preferred marketing channels. Large broadacre farmers, in other words, did not emerge with significantly different motivations to small horticultural farmers. Neither were there any meaningful differences between the motivations of those who had converted existing farms to organic practices and those who had started up as certified organic growers. There was, however, a small negative correlation between graziers' expectations 
of growth in organic beef output and their level of motivation towards environmental health (rho=-.272, $\mathrm{p}=.024)$. This group also held less strong beliefs about the seriousness of land degradation ( $\mathrm{rho}=-.339, \mathrm{p}=.009$ ), as did expansion-oriented cereal producers $(\mathrm{rho}=-.404, \mathrm{p}=.024)$. Among cereal growers there was a small correlation between the length of time they had been certified as an organic producer and their level of motivation towards environmental health $(\mathrm{rho}=.292, \mathrm{p}=.042)$, but this was not the case among beef graziers. Again, this does not mean that expansion-oriented beef and cereal producers were not concerned about the environment but that they were, relatively speaking, not quite as concerned as those graziers and cereal farmers intending lower rates of growth or even reductions in output.

Table 6: Scale items and reliability-attitudes to issues facing Australian agriculture

\begin{tabular}{|c|c|c|}
\hline Scale & Items & $\begin{array}{l}\text { Reliability } \\
\text { (Cronbach's } \\
\text { alpha) }\end{array}$ \\
\hline \multirow{4}{*}{$\begin{array}{l}\text { Seriousness of } \\
\text { land degradation }\end{array}$} & Most rural properties have some form of land degradation & .6357 \\
\hline & $\begin{array}{l}\text { Some marginal types of country in Australia will never be able to be farmed } \\
\text { or grazed without badly damaging the land }\end{array}$ & \\
\hline & $\begin{array}{l}\text { Compared to what happened in the past, the amount of land degradation } \\
\text { occurring now in Australia is relatively minor (reversed) }\end{array}$ & \\
\hline & $\begin{array}{l}\text { Land used for agriculture in Australia is in better condition than it has ever } \\
\text { been (reversed) }\end{array}$ & \\
\hline \multirow{3}{*}{$\begin{array}{l}\text { Responsibility } \\
\text { to address land } \\
\text { degradation }\end{array}$} & $\begin{array}{l}\text { People who knowingly pollute the countryside are just as criminal as } \\
\text { people who steal }\end{array}$ & .5420 \\
\hline & All necessary soil conservation methods should be used, whatever the costs & \\
\hline & $\begin{array}{l}\text { It is worth putting up with a small decrease in profits to protect the } \\
\text { environment }\end{array}$ & \\
\hline \multirow[t]{5}{*}{ Compensation } & $\begin{array}{l}\text { It is only fair that managers of rural land should be fully compensated for } \\
\text { any changes they have to make to their management for environmental } \\
\text { reasons }\end{array}$ & .6720 \\
\hline & $\begin{array}{l}\text { If restrictions on clearing or irrigation water mean any loss of income for } \\
\text { farmers, they have every right to be fully compensated }\end{array}$ & \\
\hline & $\begin{array}{l}\text { If governments have decided that the rivers need more water for } \\
\text { environmental purposes, it is unfair to expect irrigators to give up their } \\
\text { water without being compensated for their losses }\end{array}$ & \\
\hline & $\begin{array}{l}\text { Environmental laws have imposed uncompensated restrictions on } \\
\text { businesses in the city, so farm businesses should not expect compensation } \\
\text { either (reversed) }\end{array}$ & \\
\hline & $\begin{array}{l}\text { Farmers have gained benefits from clearing much of their country, so } \\
\text { they should not expect to be compensated for leaving remaining bush } \\
\text { untouched (reversed) }\end{array}$ & \\
\hline \multirow[t]{2}{*}{$\begin{array}{l}\text { Genetic } \\
\text { engineering }\end{array}$} & $\begin{array}{l}\text { Environmental benefits of genetic engineering outweigh possible risks to } \\
\text { the environment }\end{array}$ & $.9 \mathrm{II} 4$ \\
\hline & $\begin{array}{l}\text { Release of genetically modified organisms for use in agriculture poses a } \\
\text { threat to agricultural export markets (reversed) }\end{array}$ & \\
\hline
\end{tabular}


Genetic engineering continued...

Organic food quality

Industrialised food risks
Genetic modification in agriculture will enable us to better meet consumer needs

Access to genetic engineering technologies will assist agricultural producers to maintain international competitiveness

Use of genetic engineered crops will not make farming systems more sustainable (reversed)

Genetic engineering will allow agricultural producers to better feed the worlds growing population

Use of genetically modified plants and animals should be allowed in organic agriculture

Organic foods have lower chemical residues than conventional foods

.8002

Organic foods have no more vitamins and minerals than conventional foods (reversed)

Organic foods are safer to eat than conventional foods

Organic food is healthier to eat than conventionally grown food

Organic food tastes better than conventional food

Organic food has a shortened shelf life (reversed)

How high do you consider the risk posed to consumers by the ingestion of .8265 foods produced using pesticides and other chemicals

How high do you consider the risk posed to consumers by the ingestion of foods produced using genetically modified organisms

How high do you consider the risk posed to consumers by the ingestion of foods produced using preservatives and artificial colouring

How high do you consider the risk posed to consumers by the ingestion of foods produced using hormones and antibiotics in meat
9II4

Table 6 shows items and scale reliability for attitudes towards key issues facing organic food and agriculture. Items on the seriousness of land degradation did not deal with whether or not land degradation was good or bad, but with whether or not environmental conditions were deteriorating and the inevitability of this outcome. Farmers' responsibility to address land degradation addressed the financial and legal implications of reversing or avoiding environmental damage. Debates concerning the appropriateness of compensating for restrictions placed on private property rights to protect environmental values have emerged in recent years due to a number of regulatory actions including restrictions on tree clearing and reductions in water allocations. These items addressed who should pay when changes in environmental management increase the costs of production or reduce its profitability. Items related to genetic engineering addressed purported environmental, productivity and market benefits and risks specific to agriculture. The quality and safety of organic food items similarly dealt with specific food attributes such as vitamin content and taste. The scale on risks to consumers from consumption of industrially-produced foods directed questions relevant to the anxiety many consumers are alleged to feel towards chemical use, artificial additives, irradiation and the new biotechnologies to producers. 
Figure 3: Mean scores among organic and conventional farmers —attitudes to issues facing food and agriculture

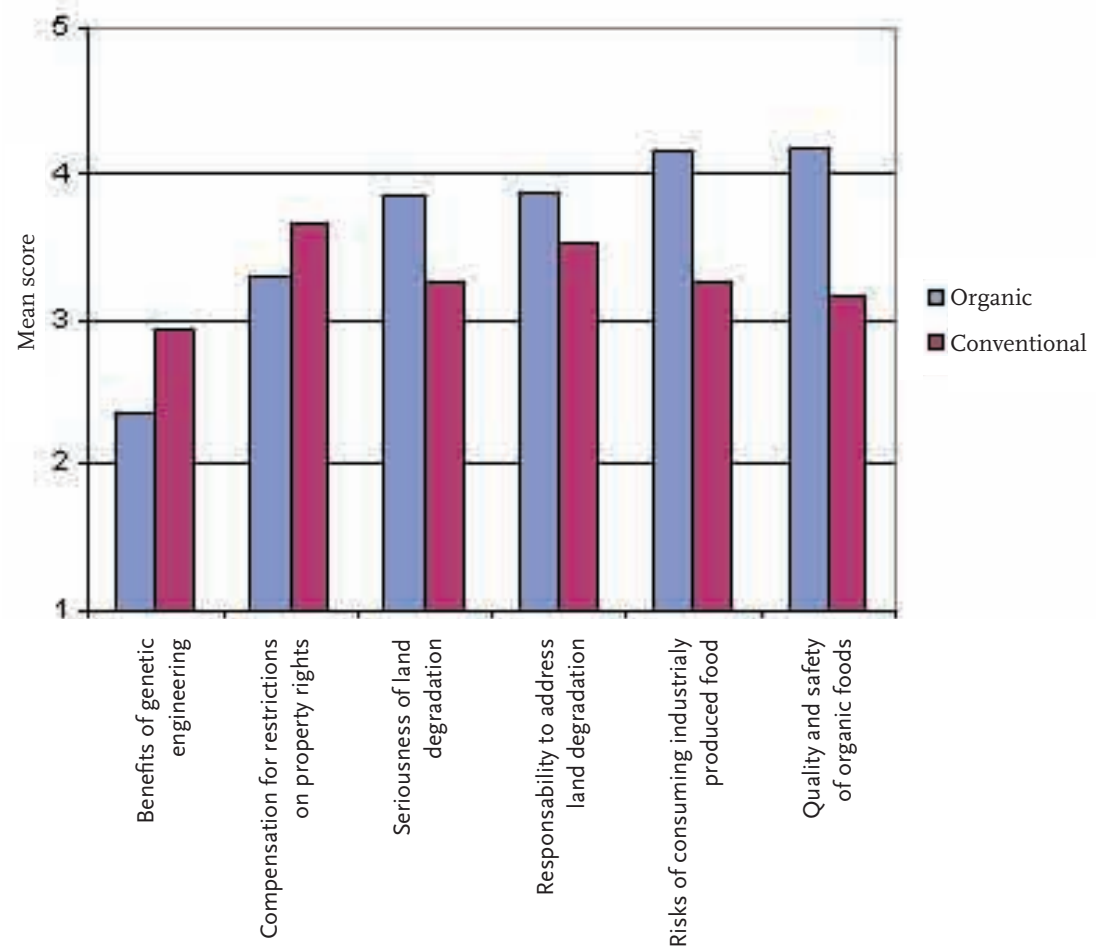

There were highly significant differences between organic and conventional farmers in relation to each of the attitudinal scales (see Table 7 and Figure 3). Organic farmers felt very strongly about the quality and safety of organic foods, the risks involved in consuming industrially-produced foods, the responsibility to address land degradation and the seriousness of land degradation. Slightly more organic farmers were in agreement that farmers should be compensated for restrictions on their property rights than were in disagreement, but they were almost wholly unconvinced of the benefits of genetic engineering. By contrast, conventional farmers felt most strongly that while they had a responsibility to address land degradation they should be compensated for any costs that are imposed on them. Conventional farmers were slightly more likely to agree than disagree that organic foods were safe and of high quality, that industrial food growing and processing methods posed risks to consumers, and that land degradation was serious. They were, perhaps surprisingly, somewhat ambivalent and sceptical overall about the benefits of genetic engineering. As Table 7 shows, this scale was the one that demonstrates the lowest standard deviation. In other words, while most of the issues about which conventional and/or organic producers appeared, on average, to be somewhat ambivalent actually polarised producers between those who agreed and disagreed, very few respondents were strongly convinced about the benefits of genetic 
engineering. Examination of specific items shows that conventional farmers did agree that genetic engineering offered potential productivity and consumer benefits, but that they also agreed that it posed risks for agriculture and was unlikely to offer substantial environmental or animal welfare benefits.

Table 7: Mean scores and t values for organic and conventional farmers — attitudes to key issues facing agriculture

\begin{tabular}{|c|c|c|c|c|c|c|c|}
\hline & $\begin{array}{l}\text { Are you a } \\
\text { certified } \\
\text { organic } \\
\text { producer? }\end{array}$ & $\mathrm{N}$ & Mean & $\begin{array}{c}\text { Std. } \\
\text { Deviation }\end{array}$ & $\begin{array}{l}\text { Std. Error } \\
\text { Mean }\end{array}$ & t-value & Significance \\
\hline \multirow{2}{*}{$\begin{array}{l}\text { Seriousness of land } \\
\text { degradation }\end{array}$} & YES & 3II & 3.8505 & .7126 & 4.०4IE-O2 & \multirow[t]{2}{*}{ II. 234} & \multirow[t]{2}{*}{$.000 * * *$} \\
\hline & $\mathrm{NO}$ & 354 & $3.257 \mathrm{I}$ & .6387 & $3.394 \mathrm{E}-\mathrm{O} 2$ & & \\
\hline \multirow{2}{*}{$\begin{array}{l}\text { Responsibility } \\
\text { to address land } \\
\text { degradation }\end{array}$} & YES & 355 & 3.8667 & .6 Igr & $3.286 \mathrm{E}-02$ & \multirow[t]{2}{*}{$7 \cdot 428$} & \multirow[t]{2}{*}{$.000 * * *$} \\
\hline & NO & 391 & 3.5277 & .6254 & $3.16_{3} \mathrm{E}-\mathrm{O} 2$ & & \\
\hline \multirow{2}{*}{$\begin{array}{l}\text { Compensation for } \\
\text { restrictions on property } \\
\text { rights }\end{array}$} & YES & 317 & $3.292 \mathrm{I}$ & .7799 & $4.380 \mathrm{E}-\mathrm{O} 2$ & \multirow[t]{2}{*}{-6.692} & \multirow[t]{2}{*}{$.000 * * *$} \\
\hline & $\mathrm{NO}$ & 357 & 3.6555 & $.606 \mathrm{I}$ & $3.208 \mathrm{E}-02$ & & \\
\hline \multirow{2}{*}{$\begin{array}{l}\text { Benefits of genetic } \\
\text { engineering }\end{array}$} & YES & 334 & 2.3636 & .3968 & $3.315 \mathrm{E}-02$ & \multirow[t]{2}{*}{$-\mathrm{I} 3.523$} & \multirow[t]{2}{*}{$.000 * * *$} \\
\hline & NO & 247 & 2.9323 & $.566 \mathrm{I}$ & 5.59 IE-O2 & & \\
\hline \multirow{2}{*}{$\begin{array}{l}\text { Quality \& safety of } \\
\text { organic foods }\end{array}$} & YES & 319 & 4.1808 & .4916 & $2.752 \mathrm{E}-\mathrm{O} 2$ & \multirow[t]{2}{*}{19.035} & \multirow[t]{2}{*}{$.000 * * *$} \\
\hline & $\mathrm{NO}$ & $\mathrm{I} 62$ & 3.1574 & .5878 & $4.618 \mathrm{E}-02$ & & \\
\hline \multirow{2}{*}{$\begin{array}{l}\text { Risks of consuming } \\
\text { industrially-produced } \\
\text { food }\end{array}$} & YES & 300 & 4.1573 & .6560 & $3.787 \mathrm{E}-02$ & \multirow[t]{2}{*}{ I 4.315} & \multirow[t]{2}{*}{$.000 * * *$} \\
\hline & NO & 254 & 3.2579 & .7990 & $5.014 \mathrm{E}-\mathrm{O} 2$ & & \\
\hline
\end{tabular}

Note: t-value calculated on unequal variance where Levene's Test for Equality of Variances $\mathrm{p}<.05$. Otherwise equal variance assumed

Among organic farmers there were no meaningful relationships, again, between start-up and converting organic farm operators. However, there were a number of relationships between the size of farms, projected expansion in productivity and attitudes to a range of environmentally-related issues. Larger farms, in spatial and economic terms, were slightly less convinced of the seriousness of land degradation ( $\mathrm{rho}=-.2 \mathrm{I} 4, \mathrm{p}=.000$ and $\mathrm{rho}=-.2 \mathrm{I} 8, \mathrm{p}=.000)$. Larger farms economically were also slightly more convinced that farmers should be compensated for restrictions on property rights to protect environmental values (rho=.206, $\mathrm{p}=.00 \mathrm{I})$. This pattern was repeated through the major commodity groups. There was a moderate negative relationship between the spatial scale of beef operations and the perceived seriousness of land degradation ( $\mathrm{rho}=-.3 \mathrm{I} 3$, $\mathrm{p}=.008$ ). Larger beef graziers were similarly less concerned about the seriousness of land degradation ( $\mathrm{rho}=-.347, \mathrm{p}=.008$ ) and more convinced farmers should be compensated 
for restrictions on property rights $(\mathrm{rho}=.266, \mathrm{p}=.045)$. There was strong relationship among cereal growers between gross farm receipts and lower levels of concern about the seriousness of land degradation (rho=-.50I, $\mathrm{p}=.004$ ). Larger cereal growers also believed they had less responsibility to address land degradation (rho=-.394, p=.oI6) but the higher the proportion of income cereal growers derived from organic production the stronger their belief that farmers did have responsibility ( $\mathrm{rho}=.349, \mathrm{p}=.025$ ) Importantly, these pattens were not restricted to broadacre farmers. Again, there was a negative relationship between total farm area and the perceived seriousness of land degradation among vegetable (rho=-.28I, $\mathrm{p}=.005)$ and fruit $(\mathrm{rho}=. \mathrm{I} 83, \mathrm{p}=.039)$ growers.

Among broadacre farmers there were moderate to strong negative relationships between estimated growth in production over the period 2005-2007 and the perceived seriousness of land degradation. Relevant commodity groups included beef (rho=-.339, $\mathrm{p}=.009$ ) and cereals, legumes and oilseeds ( $\mathrm{rho}=-.404, \mathrm{p}=.024)$. At first glance there also appeared to be a strong negative relationship between size and projected expansion in the beef industry and implementation of key environmental management practices including the fencing of degraded areas to exclude livestock. However, these were not statistically significant and were contradicted by opposite (but also not statistically significant findings) in other industries.

Farm size also was related to the perceived quality and safety of organic foods. Overall, there was a small negative correlation between gross farm receipts and organic food quality (rho=-.I23, $\mathrm{p}=.049$ ). This relationship was stronger among beef producers (rho=-.313, $\mathrm{p}=.023)$. Conversely, there was a small positive relationship between the total organic area on fruit farms and perceptions of quality and safety (rho=.194, $\mathrm{p}=.030$ ).

\section{Discussion}

The Australian organic industry certainly was characterised in 2004 by dramatic differences in farm scale-economically and spatially. Further, this polarisation was strongly correlated with farm enterprise mixes; the broadacre grazing and cropping industries grossing considerably higher farm receipts as well as utilising greater landholdings. Potential reasons for crop-based polarisation include the extensive land, and consequently capital, requirements of broadacre farming in Australia which may be expected to present more formidable barriers to entry than smallholder horticulture. It is tempting also to speculate that smallholder horticulture may be more appealing to those committed to the pursuit of non-material goals such as self-sufficiency, intentional communities or social movement building. Taken together with the dominance of growth in exports by broadacre crops this would appear, at face value, to mirror the early trends towards bifurcation between large, recently converted and export-oriented growers and smaller, movement-based and domestically-oriented farmers identified by Coombes and Campbell (1998) in New Zealand. That is, it appears to support the broad claims of the conventionalisation thesis. Such speculations and conclusions are not, however, consistent with all the data presented above on the Australian situation.

To begin, there is no compelling evidence that the existing level of polarisation, or concentration, with the organic production sector is likely to increase in the immediate future. While the number of certified growers may increase somewhere in the order of 40 percent in the next three years, existing trends suggest this is likely to comprise a 
constant mix of smaller and larger operators while existing growers expect to increase their own output, depending on product category, by something in the vicinity of 30 to I50 percent. Further, while individual expectations of change in production levels vary widely within each product category, this variation is unrelated to the existing scale of production and gives us at least two reasons to suspect that expansion of the production sector, at least in the short-term, may even lead to a small decrease in capital concentration. First, intended levels of expansion in the beef industry were positively correlated with existing output of conventional livestock, meaning that some of the intended expansion among beef graziers will be accounted for by the conversion of conventionally-farmed livestock to organic husbandry methods rather than through increases in gross farm output. Second, there were substantially higher rates of growth forecast in smallholder dominated sectors such as horticulture and intensive livestock. Irrespective of the values and beliefs of smallholder organic producers (non-material or otherwise), these certainly did not appear to serve as a barrier to ambitions to expand output. While it is possible to interpret this as consistent with a logic of capitalist development in which increasing economies of scale are required to maintain viability as margins decrease and land rents increase (Guthman 2004b), there is no evidence that these specific processes affect Australian smallholders nor that they compromise their ability to sustain livelihoods based on minimum consumption and/or off-farm income.

It is important to note that short-term limits on capital concentration in the production sector do not necessarily represent the dynamics of other stages within the organic food chain such as input supply, trading, processing and retailing, on which data was not collected. It is also important to note that short-term limits on capital concentration in the production sector may rapidly be undermined should other actors within the organic food chain alter their own strategies in relation to the production sector. A number of mechanisms have been identified in the literature through which actors in the input supply, distribution, processing and retail sectors may come effectively to control the onfarm production process despite the survival of large numbers of owner-operator farm enterprises. These include the creation of dependencies for technological, intellectual and capital inputs and the control of marketing channels via monopolies, contract farming arrangements etc (Goodman et al. I987). In the organic production sector, case studies have identified instances where these mechanisms have been deployed in parallel with the additional strategy of sponsoring large conventional growers to convert in order to secure larger, cheaper and more consistent product supply (Guthman 2004b; Lockie et al. 2000; Smith and Marsden 2003). Rumours abound within the Australian organic industry that large retailers are considering the implementation of these strategies on a wider scale. However, as Hall and Mogyorody (200I) point out, contract farming arrangements often are regarded favourably by growers of all sizes and ideological dispositions due to their utility as a risk management strategy in the face of potential market instability (see also Lockie I997; Tonts et al. 2004), making it difficult to predict what the outcomes of more formalised relationships between growers and intermediaries might be. The use by existing organic growers of a limited number of market outlets accessed via informal arrangements is interesting in this light. In the absence of data on the availability to producers of alternative intermediaries and so on it is impossible to do more than speculate on the degree of flexibility this informality affords them relative to the controls they may face should their options be more limited. 
However, flexibility is likely to vary widely across commodity sectors due to the need for some products, such as cereals and oilseeds, to be processed before sale and the need, therefore, for access to certified organic processors of which there are comparatively few. The widespread use among small and large farmers alike of marketing a small, but significant, proportion of output direct to consumers-despite the considerable distances often between producers and consumers in Australia-suggests that this may be interpreted, in many cases, more as a market diversification strategy than an commitment to values of local production and consumption.

The fact that the scales used here to measure farming motivations and attitudes and beliefs in relation to key issues facing food and agriculture elicited strong and intuitive differences between organic and conventional producers suggests these measures do differentiate satisfactorily among producers. It is telling, therefore, that there were no significant differences among organic growers of different sizes or market orientations in relation to their motivations for farming. Large and small farmers were equally likely to rate chemical safety, food quality, environmental health and animal health as their most important motivating factors. They were also equally likely to rate the community-oriented concern of rural development as their least important motivating factor. The same was the case in relation to start-up and converting farm operations with no meaningful differences between those with conventional farming experience prior to entry into the organic industry. While it is entirely possible that, like many values, farmers may construct and operationalise these motivating factors in different ways in their own farming operations (they may not, for example, agree on the best way to maintain animal health and wellbeing), it remains the case that they do agree that these are the things that dominate their thinking about what it means to be a good farmer. Further, it is important to note that the motivational and attitudinal differences between organic and conventional farmersdespite their strength-were differences of degree, not direction. In other words, while organic and conventional farmers tended to agree with each other on most points, organic farmers tended to express their views more forcefully. This finding suggests a more subtle ideological cleavage between conventional and organic sectors than the 'gulf' often asserted or implied by scholars and the organic movement

The finding that expansion-oriented broadacre farmers were slightly less motivated towards environmental health should not be interpreted to mean that they were not at all concerned about the environment (as the lower level of motivation among conventional farmers should not). It cannot be discounted, after all, that some farms objectively may face less serious degradation and degradation hazards than other farms, and this is particularly likely to be true of conservatively stocked rangeland grazing enterprises that use few chemicals even under conventional production. It would make sense, following this, that such farmers would not believe land degradation to be as serious or perhaps that they are less responsible for doing things to address it than would other farmers. The possibility that some farms objectively face less degradation would not seem to be able to account, however, for the negative correlations between farm size (economically and spatially) and the perceived seriousness of, and responsibility to address, land degradation across other production sectors. A more likely explanation would seem to lie in farmers' peer networks and the potential for higher degrees of integration of larger organic farmers within conventional farming networks and cultures. However, the survey also found little evidence to support this with no relationship between farm size and membership of 
farmers' associations and only a very small relationship with membership of Landcare or catchment management groups (rho=.I60, $\mathrm{p}=.005$ ). Great care should be taken, therefore, in interpreting the above findings as a conventionalisation of beliefs and attitudes among larger organic farmers. If scholars wish to maintain that beliefs can be 'coventionalised' then some mechanism and process needs to be envisaged and evidence of the outcome of such a process provided.

\section{Conclusion}

The data presented here do not speak to all potential aspects of conventionalisation. However, by demonstrating that polarisation in the economic scale of the Australian organic industry does accord with some aspects of the so-called conventionalisation thesis, but not with others, we hope to have demonstrated the need to extend debate over the conventionalisation thesis beyond the question of whether or not it is occurring and, if so, at what rate. More specifically, we hope also to have demonstrated the need to unpack the concept of conventionalisation and avoid an uncritical aggregation of multiple dualisms between small and large, artisanal and industrial, radical and regulatory, local and international, regenerative and substitutionist, and so on through the related concept of bifurcation. In the production sector, at least, of the Australian organic industry concentration is occurring in relation to the expansion of organic enterprises, but not in terms of increasing polarisation between organic farmers. Rather than de-radicalising the organic industry, growth in farm numbers seems to have resulted in a larger sector in which the values and beliefs motivating organic farmers are shared with more-or-less equal passion by older and newer members of the industry alike. To be sure, some apparently more movement-oriented goals such as community development were less important to the majority of growers and we have no doubt that there are members, or former members, of the sector who find the value structure of the industry conservative. Nevertheless, this was no more the case among newer, larger or converting organic growers than among longerterm, smaller or start-up organic growers. Finally, while differences were evident between smaller and larger organic growers in relation to their beliefs about the seriousness of land degradation there were some (not statistically significant) suggestions in the data that larger and more rapidly expanding farms in some product sectors had implemented more environmental management practices, and that in other sectors they had implemented less. Understanding the basis for differences in the environmental beliefs and practices of farmers in different sectors and operating at different scales clearly requires exploring in more depth the interplay of social networks and agroecologies, not the straightforward attribution of conventionalised beliefs and attitudes.

The concepts of conventionalisation and bifurcation carry with them a not so subtle normative claim that the transformative potential of the organic industry is threatened by an incoming 'conventional element'. Yet the evidence suggests there has been no conventional takeover of the Australian organic sector-at least not one that is evident in the thinking of organic newcomers. Newcomers and long-standing organic producers have more in common than the bifurcation concept allows. Indeed, both share the same degree of variability in terms of motivations and in terms of farm structure and scale. This simple finding is sufficient to throw doubt on the bifurcation elements (both ideological and structural) of the conventionalisation thesis. Clearly, the uncritical 
adoption of concepts such as conventionalisation and bifurcation is problematic. The prominence of these concepts in debates over organic agriculture may be motivated by the desire to make sense, in the absence of comprehensive data, of rapid processes of social change, or by the desire to make an ideological fit with movement goals that scholars identify with or have sympathy for. Either way, theorising change within the organic sector needs to be underpinned both by more detailed empirical study and by more critical scrutiny of normative assumptions such as organic equals 'good' and conventional equals 'bad'.

In defence of organic scholars, the same criticisms may be levelled at a variety of concepts purporting either to describe or explain change within agriculture and rural communities: 'post-productivism' and its derivatives among the most conspicuous. Without wishing to distract from our discussion of organic production, we would like to conclude by arguing that, in a round about fashion, concepts such as post-productivism offer useful insights into future directions for theorising and researching processes of conventionalisation. As with conventionalisation, academic discussion largely has accepted that in contemporary rural change (particularly in the UK) we are witnessing the emergence of a 'post-productivist countryside' that is qualitatively different from the agri-industralised landscapes of 'conventional' agriculture (Marsden I998; Ilbery and Bowler I998). Again, as with conventionalisation, dissenting voices have protested the universality and inevitability of post-productivism (Argent 2002; Hoggart and Paniagua 200I), but few have questioned its underlying assumptions. We would suggest that in conceptualising post productivism, the ways in which agricultural policy is made (institutional changes) and the ways in which policy makers talk about, foreshadow and frame policy (policy frames/images) has been interpreted as a meso-level theory to describe and explain actual processes of change in farming communities. With post-productivism and conventionalisation alike, the particularly important question to emerge is how these processes of 'talking about' and 'framing' change actually influence both conceptual and empirical developments. Research usefully might focus, therefore, on how ideas of conventionalisation are used by researchers and organic activists in order to actively govern, discipline and steer the organic sector. While we might speculate that conventionalisation and bifurcation are used as defensive rhetorical devices to internally 'police' the direction of the organic sector by identifying undesirable elements against which to campaign, such speculations must themselves be put to empirical scrutiny.

\section{References}

Argent, N. (2002) From pillar to post? In search of the post-productivist countryside in Australia Australian Geographer 33(I) pp. 97-II4

Buck, D., C. Getz and J. Guthman (I997) 'Archaic' relations of production in modern agricultural systems: the organic vegetable commodity chain of Northern California. Sociologia Ruralis 37 (I) pp. 3-I9

Campbell, H. and B. Coombes (I999) Green protectionism and organic food exporting from New Zealand: crisis experiments in the breakdown of Fordist trade and agricultural policies. Rural Sociology 64(2) pp. 302-319

Campbell, H. and R. Liepens (200I) Naming organics: understanding organic standards in New Zealand as a discursive field. Sociologia Ruralis 4I(I) pp.2I-39

Coombes, B. and H. Campbell (1998) Dependent reproduction of alternative modes of agriculture: organic farming in New Zealand. Sociologia Ruralis 38(2) pp. I27-I45 
Goodman, D. (I999) Agro-food studies in the 'age of ecology': nature, corporeality, biopolitics. Sociologia Ruralis 39(I) 00. I7-38

Goodman, D., B. Sorj and I. Wilkinson (1987) From Farming to Biotechnology: A Theory of AgroIndustrial Development (Oxford: Basil Blackwell)

Guthman, J. (1998) Regulating meaning, appropriating nature: the codification of California organic agriculture. Antipode 30 (2) pp. I35-I54

Guthman, J. (2000) Raising organic: an agro-ecological assessment of grower practices in California. Agriculture and Human Values I7 pp. 257-266

Guthman, J. (2004a) The trouble with 'organic lite' in California: a rejoinder to the 'conventionalisation' debate. Sociologia Ruralis 44(3) pp. 30I-3I6

Guthman, J. (2004b) Back to the land: the paradox of organic food standards. Environment and Planning A 36 pp. 5II-528

Guthman, J. (2004c) Agrarian Dreams: The Paradox of Organic Farming in California (Berkeley: University of California Press)

Hall, A. and V. Mogyorody (200I) Organic farmers in Ontario: an examination of the conventionalization argument. Sociologia Ruralis 4I(4) pp. 399-422

Halpin, D. (2004) Australian Organic Industry Profile (Canberra: Department of Agriculture, Fisheries and Forestry)

Hoggart, K. and A. Paniagua (200I) What is rural restructuring? Journal of Rural Studies I7 pp.4I-62

Ilbery, B. and I. Bowler (I998) From agricultural productivism to post-productivism. Pp 57-84 in B. Ilbery ed., The Geography of Rural Change (Harlow: Addison Wesley Longman).

Jordan, S., S. Hisano and R. Izawa (2004) Conventionalisation in the Australian organic industry: a case study in the Darling Downs region. Paper presented to Post-Organic Futures Workshop, World Congress of Rural Sociology, Trondheim, Norway, July.

Kaltoft, P. (200I) Organic farming in late modernity: at the frontier of modernity or opposing modernity? Sociologia Ruralis 4I(I) pp. I46-I58

Kaltoft, P. and M. Risgaard (2004) Has organic farming modernised itself out of business? an analysis of reverting organic farmers. Paper presented to Post-Organic Futures Workshop, World Congress of Rural Sociology, Trondheim, Norway, July.

Lockie, S. (I997) Is 'subsumption' still relevant? The question of control in Australian broadacre agriculture. Rural Society 7(3/4) pp. 27-36

Lockie, S. (forthcoming) Capturing the sustainability agenda: organic foods and media discourses on food scares, environment, genetic engineering and health. Agriculture and Human Values

Lockie, S., K. Lyons and G. Lawrence (2000) Constructing 'green' foods: corporate capital, risk and organic farming in Australia and New Zealand. Agriculture and Human Values i7(4) pp. $315-322$

Lockie, S., K. Lyons, G. Lawrence and K. Mummery (2002) Eating green: motivations behind organic food consumption in Australia. Sociologia Ruralis 42(I) pp. 20-37

Lyons, K. (1999) Corporate Environmentalism and organic agriculture in Australia: the case of Uncle Tobys. Rural Sociology 64(2) pp. 25I-265

Lyons, K. (200I) From sandals to suits: green consumers and the institutionalisation of organic agriculture. Pp. 82-93 in S. Lockie and B. Pritchard eds., Consuming Foods, Sustaining Environments (Brisbane: Australian Academic Press)

Marsden, T. (I998) New rural territories: regulating the differentiated rural spaces. Journal of Rural Studies I4(I) pp.I07-II7

Michelsen, J. (200Ia) Recent development and political acceptance of organic farming in Europe. Sociologia Ruralis 4I(I) pp. 3-20

Michelsen, J. (200Ib) Organic farming in regulatory perspective: the Danish case. Sociologia Ruralis 4I(I) pp. 62-84 
Moore, O. (2004) Farmers' markets, and what they say about the perpetual post organic movement in Ireland. Paper presented to Post-Organic Futures Workshop, World Congress of Rural Sociology, Trondheim, Norway, July

Moore, S. (2003) Organic industry snapshot. In Organic Food and Farming Report 2003 (Toowoomba, QLD: Biological Farmers of Australia)

Mutersbaugh, T. (2002) The number is the beast: a political economy of organic-coffee certification and producer unionism. Environment and Planning A 34 pp. II65-II84

Mutersbaugh, T. (2004) Serve and certify: paradoxes of service work in organic-coffee certification. Environment and Planning D 22 pp. 533-552

Padel, S. (200I) Conversion to organic farming: a typical example of the diffusion of innovation? Sociologia Ruralis 4I(I) pp. 40-6I

Pugliese, P. (200I) Organic farming and sustainable rural development: a multifaceted and promising convergence. Sociologia Ruralis 4I(I) pp. II2-I3O

Reeve, I. (200I) Australian Farmers' Attitudes to Rural Environmental Issues: 1991-2001 (Armidale, NSW: Institute for Rural Futures)

Smith, P. (2003) Organic food: an Australian perspective. In Australian Food Statistics 2003 (Canberra: Agriculture, Fisheries and Forestry Australia)

Smith, E. and T. Marsden (2003) Exploring the 'Limits to Growth' in UK Organics: Beyond the Statistical Image (Cardiff: The Centre for Business Relationships, Accountability, Sustainability and Society)

Steptoe, A., T. Pollard and J. Wardle (I995) Development of a measure of the motives underlying the selection of food: the food choice questionnaire. Appetite 25 pp. $267-284$

Tonts, M., D. Halpin, J. Collins and A. Black (2004) Rural Communities and Changing Farm Business Structures: An Assessment of the Socio-Economic Impacts (Canberra: Rural Industries Research and Development Corporation).

Tovey, H. (1997) Food, environmentalism and rural sociology: on the organic farming movement in Ireland. Sociologia Ruralis 37 (I) pp. 2I-37

Tovey, H. (2002) Alternative agriculture movements and rural development cosmologies. International Journal of the Sociology of Agriculture and Food 6(2) pp. I-II

Yussefi, M (2003) Australia and Oceania. Pp. 65-7I in M. Yussefi and H. Willer eds., The World of Organic Agriculture: Statistics and Future Prospects (Tholey-Theley: International Federation of Organic Agriculture Movements)

Stewart Lockie

Centre for Social Science Research

Central Queensland University

Rockhampton QLD 4702 Australia

Darren Halpin

Department of Economics and Public Policy

Robert Gordon University

Garthdee Road

Aberdeen $A B 10$ 7QE Scotland 